\title{
Salt-affected soils on elevated landforms of an alluvial megafan, northern Pantanal, Brazil
}

Jairo C. Oliveira Junior ${ }^{\mathrm{a}}$, Sheila A.C. Furquim ${ }^{\mathrm{b}}$, Alexandre F. Nascimento ${ }^{\mathrm{c}}$; Raphael M. Beirigo ${ }^{\mathrm{d}}$; Laurent Barbiero $^{\mathrm{e}}$, Vincent Valles ${ }^{\mathrm{f}}$, Eduardo G. Couto ${ }^{\mathrm{g}}$; Pablo Vidal-Torrado ${ }^{\mathrm{h}}$

${ }^{a}$ Department of Soil and Agricultural Engineering, Federal University of Paraná, Curitiba, Brazil.

${ }^{\mathrm{b}}$ Department of Environmental Sciences, Federal University of São Paulo, Diadema, Brazil.

${ }^{\mathrm{c}}$ Embrapa Agrossilvipastoril, EMBRAPA, Sinop, Brazil

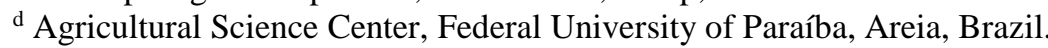

${ }^{\mathrm{e}}$ IRD, CNRS, UPS, OMP, Géoscience Environnement Toulouse, France.

${ }^{\mathrm{f}}$ Laboratoire d'Hydrogéologie, Université d'Avignon et des Pays du Vaucluse, Avignon, France.

${ }^{g}$ Department of Soil and Rural Engineering, Federal University of Mato Grosso, Cuiabá, Brazil.

${ }^{\text {h }}$ Department of Soil Science, University of São Paulo, Piracicaba, Brazil.

${ }^{1}$ Corresponding author. Tel./fax: $+55413350-5658$

E-mail address: calderari@ufpr.br

\begin{abstract}
Salt-affected soils play an important role in the Pantanal wetlands ecosystem, in Brazil, but their occurrence on higher landforms is not well understood. In order to investigate the major processes involved in salt-affected soil formation, a trench was opened in a representative transition between the floodplain and a paleochannel-paleolevee complex not currently reached by floodwater. The trench was 6 meters long and 2 meters deep, and 121 soil samples were collected in a $0.25 \times 0.25 \mathrm{~m}$ regular grid and submitted for soil (particle-size, $\mathrm{pH}$, exchangeable cations) and solution extract (major cation and anions) analyses. Analytical results were subjected to geostatistical and principal components analyses (PCA). For selected horizons, an undisturbed sample was collected to perform thin sections and micromorphology description. The presence of degraded carbonates in the soils indicated an ancient formation. The regional environmental settings of the alluvial fan and particle size variation along the soil profiles suggested that the sediments of the study site were deposited during the Late Pleistocene and Holocene, in a river channel-levee complex and an abandoned channel by avulsion processes. The depressed topography of the abandoned channel, accompanied by moderately drier climates during early Holocene, likely favored low leaching of salts and higher evapotranspiration, enabling the development of salt-affected soils. Later erosion of the region, which is expected in older lobes of alluvial fans, triggered a relief inversion in the area, preserving the more clayey areas as a slightly higher landform with remaining salt-affected soils. Currently, the seasonal flooding mainly reaches the footslope of this landform, triggering redoximorphic processes, expressed as redox concentrations and depletions, and solodization processes, expressed by lower values of $\mathrm{pH}$, cation exchange capacity (CEC), base saturation and exchangeable sodium percentage (ESP) than at the summit. Thus, the occurrence of salt-affected soils on higher landforms is the reflection of a complex sedimentological history. In this way, the genesis of salt-affected soils on higher landforms, which seems to be poorly understood in many situations worldwide, should be carefully investigated in order to address formation mechanisms, especially in extremely dynamic environments of tropical wetlands.
\end{abstract}

Keywords: Tropical wetlands, Sodic soils, evaporative concentration of waters, Quaternary climatic changes, solodization, relict soil carbonates.

\section{Introduction}

Salt-affected soils occur in more than 100 countries across the continents, occupying an area estimated at 831 to 932 million hectares (Martinez-Beltran and Manzur, 2005; Szalbolcs, 1974; Szalbolcs, 1979; Massoud, 1977; Rengasamy, 2006), which corresponds to approximately $6 \%$ of total 
land and $60 \%$ of the cultivated land in the world (Bruinsma, 2003). The excess of water-soluble salts in the profile, especially in the root zone, is toxic to plants and responsible for limitation or prevention of vegetation growth (Abrol et al., 1988; Rengasamy, 2006). When the presence of $\mathrm{Na}^{+}$in the profile is significant, the expansion and dispersion of soil colloids produce unfavorable physical properties, such as hard consistency and reduced hydraulic conductivity, increasing resistance to root penetration and erosion susceptibility (Fitzpatrick et al., 1994; Rengasamy and Sumner, 1998).

The broad group of salt-affected soils has been commonly subdivided into Saline (Solonchak), Sodic (Solonetz) or Saline-Sodic soils. Saline soils are those with accumulation of salts more soluble than gypsum and are recognized by electrical conductivity $(\mathrm{EC}) \geq 4 \mathrm{dS} \mathrm{m}^{-1}$, exchangeable sodium percentage $(\mathrm{ESP})<15$, and $\mathrm{pH}$ typically $<8.5$. Sodic Soils are characterized by the relative accumulation of exchangeable $\mathrm{Na}^{+}$, presenting ESP generally $\geq 15 \%, \mathrm{EC}<4 \mathrm{dS} \mathrm{m}^{-1}$, and extremely alkaline $\mathrm{pH}$, commonly $\geq 8.5$. Saline-Sodic has intermediate features, with both accumulation of soluble salts, expressed by EC $\geq 4 \mathrm{dS} \mathrm{m}{ }^{1}$, and relative accumulation of exchangeable $\mathrm{Na}^{+}$, expressed by ESP $\geq 15 \%$ (USSL Staff, 1954; Bohn et al., 2001).

Salt-affected soils usually occur in arid or semi-arid climates, where the hydrologic deficit most of the year enables the concentration of solutions with consequent salt precipitation, while low rainfall rates prevent intense salt leaching. However, these soils can also be formed in sub-humid and humid regions with pronounced seasonal contrast of precipitation and higher annual evapotranspiration than annual rainfall in part of the year (Sandoval and Shoesmith, 1961; Abrol et al., 1988; Bohn et al., 2001; Indorante, 2006). The temporary abundance of water found in more humid climates also facilitates the instability of aggregates, with subsequent colloid dispersion (Rengasamy and Sumner, 1998).

A source of salt combined with restricted drainage also provide conditions for the development and maintenance of salt-affected soils. The limitation of water flow, trigged by the combination of shallow water table and/or near-impervious subsurface horizons/layers with locally depressed topography, is responsible for water confinement and low levels of salt leaching, which may increase evaporation rates and aggregate instability (Westin, 1953; USSL Staff, 1954; Munn and Boehm, 1983; Indorante, 2006). Commonly, local maximum ion accumulation, expressed by the highest EC and/or ESP values, occurs in slight depressions of near-flat landscapes, floodplains, low terraces or footslope positions (Whittig, 1959; USSL, 1954; Fehrenbacher et al., 1963; Sandoval and Reichman, 1971; Abtahi, 1977; Abtahi, 1980; Fanning and Fanning, 1989; Heck and Mermut, 1992; Singh and Kar, 2001; Monteiro et al., 2012). To a much lesser extent, Saline, Sodic and Saline-Sodic soils are registered on topographical highs, such as summits, upper slopes or micro-elevations. Although their genesis is not completely understood in these situations, it seems that it is related to shallow saltenriched parent material (Schaetzl and Anderson, 2005; Chernouzenko et al., 2011) or to drainage restriction as a result of shallow water table or impermeable subsurface horizons (Yang et al., 2011; Thomas et al., 2011).

The Pantanal, located in the center of South America, is one of the largest wetlands in the world, with an area of $150,500 \mathrm{Km}^{2}$ (Padovani, 2010). Although the region is under a tropical climate (Aw, according to the Koppen classification) (Alfonsi and Camargo, 1986; Alvares et al., 2013), saltaffected soils cover approximately $34 \%$ of the area (Oliveira et al., 2006), which is at least partially related to the high seasonality of precipitation (mainly in the summer) and high rates of annual evapotranspiration (1400 mm) (Alfonsi and Camargo, 1986; Por, 1995). In the Pantanal of Barão de Melgaço (18,167 km²), a sub-region located in the northern Pantanal (Silva and Abdon, 1998), both salt-affected and non-salt-affected soils occupy higher positions on the landscape, up to 5 meters above than the surroundings (Couto et al., 2017). The parent material of these lands is formed by sequences of non-saline sandy, loamy and clayey sediments deposited in an alluvial megafan (Assine et al., 2014) and the water drainage is apparently not limited during most of the year (Nascimento, 2012). 
Thus, this work aimed to study the environmental (current and past), sedimentological and geomorphological role in the formation of salt-affected soils occurring in the elevated areas of the Barão de Melgaço sub-region, in order to contribute to a better understanding of the genesis of this type of soils and their relationship with landforms formed under late Quaternary tropical climates.

\section{Location and environmental settings}

\subsection{Location of the study area}

The study was conducted in a Natural Heritage Private Reserve (RPPN), belonging to The Social Service for Commerce (Serviço Social do Comércio - SESC) in the Barão de Melgaço sub-region, northern Pantanal. The RPPN is located in central-western Brazil (Fig. 1) and is bordered by the Cuiabá River in the west and the São Lourenço River in the east, both tributaries of the left margin of the Paraguay river. The site selected for study (Fig. 1) is at 566,518 $\mathrm{m} \mathrm{E}$ and 8,147,826 m S; UTM projection system, $21 \mathrm{~K}$ zone.

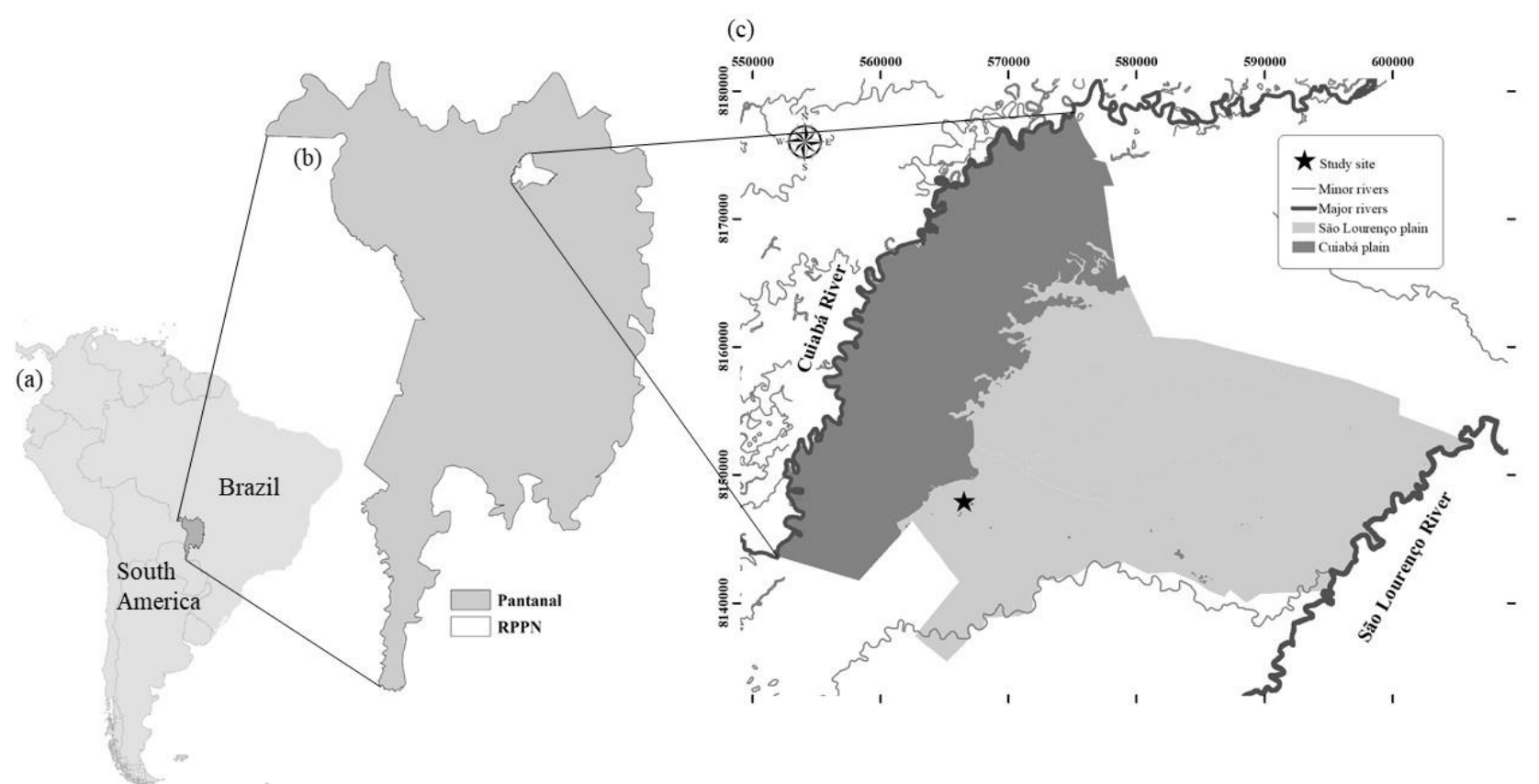

Fig. 1. Location of the Pantanal in South America and Brazil (a); location of the study region (RPPN) in northern Pantanal (from 550,000m E to $610,000 \mathrm{~m} \mathrm{E}$ and $8,180,000 \mathrm{~m} \mathrm{~N}$ to $8,130,000 \mathrm{~m} \mathrm{~N}$ ) (b); the RPPN bordered by two major rivers and the specific study site (c). Coordinates in $\mathrm{m}$, Universal Transverse Mercator (UTM) projection, zone $21 \mathrm{~K}$ (south). (Adapted from Nascimento et al., 2013.)

\subsection{Environmental settings}

The Pantanal is a huge alluvial plain, with about $150,000 \mathrm{~km}^{2}$, located mostly in Brazil, but also in minor parts of Paraguay and Bolivia (Padovani, 2010). It has altitudes between 80 and $200 \mathrm{~m}$ a.s.l. and very low slope declivities $(<0.1 \%$ ) (Alvarenga et al., 1984; Silva, 1986; Garcia, 1991), although the headwaters of its main drainage basins are in the steeper surrounding highlands (200 to $900 \mathrm{~m}$ ), formed by Precambrian crystalline and Mesozoic sedimentary rocks (Del'Arco et al., 1982). These highlands are source areas for significant amounts of water and sediment of the seasonal floods that reach the wetland mainly from January to June (Del'Arco et al, 1982; Alvarenga et al.; 1984; Godoi Filho, 1986; Por 1995; Padovani, 2010).

This wetland is a modern sedimentary basin composed of unconsolidated to semi-consolidated sediments, with maximum thickness of $500 \mathrm{~m}$, deposited in alluvial fans, floodplains, and lacustrine environments (Del' Arco et al., 1982; Assine, 2015). The specific study site is located on the São Lourenço megafan, which is the second largest fan in the wetland, with an area of approximately 
$16,000 \mathrm{Km}^{2}$ (Assine et al., 2014). Alluvial fans are marked by distributary channels, which flow from a larger river to surrounding areas. It is explained by an intense sediment accumulation in the riverlevee complex, which becomes higher than floodplain, tending to breach and deviate the flow into neighboring alluvial plains (Schumm, 1977). This process, called river avulsion, is responsible for changing river direction (Bryant et al., 1995) and tends to be very common and rapid in alluvial fans, including the São Lourenço megafan (Assine et al., 2014).

According to Nascimento (2012), two main geomorphological features are currently observed on the São Lourenço megafan: i) high topographical zones reached only by extreme inundation, comprised of paleochannels and paleolevees; ii) low topographical zones reached by annual inundation, formed mainly by alluvial plains. Some of these zones include closed or open depressions delimited by the paleochannels or paleolevees, which are formed as a result of the intermingling of the high zones through a series of ancient avulsion events (Nascimento 2012; Berendsen and Stouthamer, 2000). According to the geomorphological map, at scale $\sim 1: 155000$, produced by Nascimento (2012), the study site is in a paleochannel -paleolevee complex, up to $3 \mathrm{~m}$ higher than the surroundings. It is delimited in the north and in the south by active floodplain areas, which flood annually.

The high topographical zones of the RPPN are mainly formed by soils with textural contrasts, involving mainly Planosols (30\%) and Luvisols (6\%). Planosols in the area have dystrophic A and E horizons and eutrophic B horizons, whereas Luvisols have base saturation generally above $80 \%$ in the whole profile. The lower zones have soils affected by redoximorphic processes, mainly Plinthosols (23\%), Cambisols (13\%), Fluvisols (11\%) and Gleysols (11\%). The Plinthosols are mostly dystrophic and alumic, whereas the Cambisols are mainly fluvic and eutrophic. The Fluvisols are eutrophic and the Gleysols are mostly fluvic, dystrophic and alumic. In addition, the Luvisols, Cambisols and Fluvisols tend to have high $\mathrm{Mg}^{2+}$ saturation and the Planosols, Fluvisols and Plinthosols may have sodic and protosodic qualifiers (Beirigo et al., 2010; Couto et al., 2017).

Regardless of the magnitude of the annual flood, the Pantanal shows a negative water balance, with a deficit of $300 \mathrm{~mm}$ resulting from an annual mean precipitation of $1100 \mathrm{~mm}$ and annual mean evapotranspiration of $1400 \mathrm{~mm}$ (Alfonsi and Camargo, 1986). The climate is classified as Tropical Savanna (Aw), according Köppen's classification, with marked rainy and dry seasons from December to March and June to October, respectively (Köppen, 1936; Por, 1995). The mean annual temperatures range from 22.4 to $25.6{ }^{\circ} \mathrm{C}$, with October being the warmest month in the north (Alvarenga et al. 1984; Alfonsi and Camargo, 1986; Tarifa, 1986).

\section{Methods}

\subsection{Survey and sampling}

Spatial changes in soil electrical conductivity were first surveyed using the non-destructive electromagnetic induction method with an EM38-MK2 sensor (Geonics Ltd, Ontario, Canada) coupled with GPS. This device measured the apparent electrical conductivity (EC $\mathrm{EM}_{\mathrm{EM}}$ of the soils from the surface in $\mathrm{dS} \mathrm{m} \mathrm{m}^{-1}$ over a depth of investigation of approximately $1.7 \mathrm{~m}$. Based on the map generated from these measurements (Fig. 2), boreholes were made with a hand auger at the abrupt transition in soil $\mathrm{EC}_{\mathrm{EM}}$ measurements, at every $0.2 \mathrm{~m}$ in depth. Then, a 6-meter long, 2-meter deep trench was excavated for continuous soil observation between two boreholes with significantly different $\mathrm{EC}_{\mathrm{EM}}$ values.

The soil features in the trench was described according to FAO (2006) and studied in detail in order to reveal the geometrical relationships between the different horizons identified from field observations (Munsell chart color, texture, structure, consistency, macrovoids, presence of coarse elements, intensity of biological activity, etc). A total of 121 soil samples were collected on one lateral side of the trench along a $0.25 \times 0.25 \mathrm{~m}$ regular grid (Fig. 3) for laboratory analysis. Additional soil samples were taken from a sandy horizon at the bottom of the trench for optically stimulated luminescence (OSL) dating. The sampling was performed using PVC tubes (diameter $50 \mathrm{~mm}$ x length 
$200 \mathrm{~mm}$ ) and stored according to Wallinga et al. (2000). Undisturbed blocks were collected for thin section analysis. An arrow indicating the surface of the profile was drawn in each block in order to guarantee the orientation of the sample.

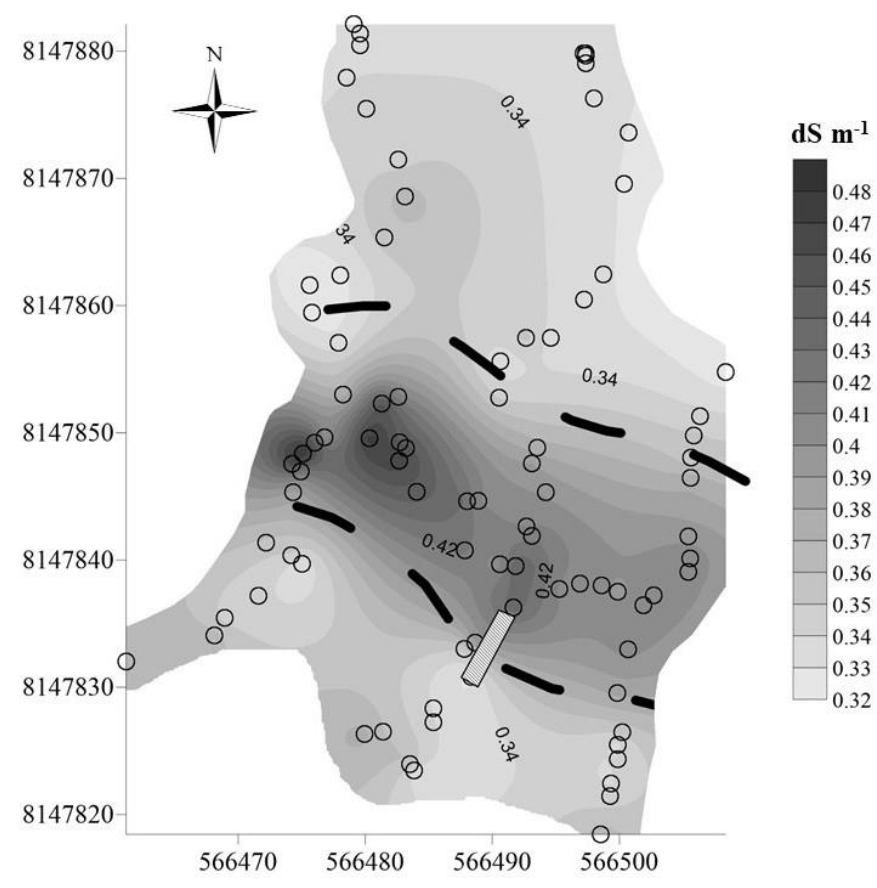

Fig. 2. Apparent electrical conductivity (ECEM - dSm-1) obtained by EM38. The open circles indicate the places of ECEM collection and the rectangular area indicates the trench location. Bold dashed lines represent the extent of the paleochannel - paleolevee complex. Coordinates in m, Universal Transverse Mercator Projection (UTM), zone $21 \mathrm{~K}$ (south).

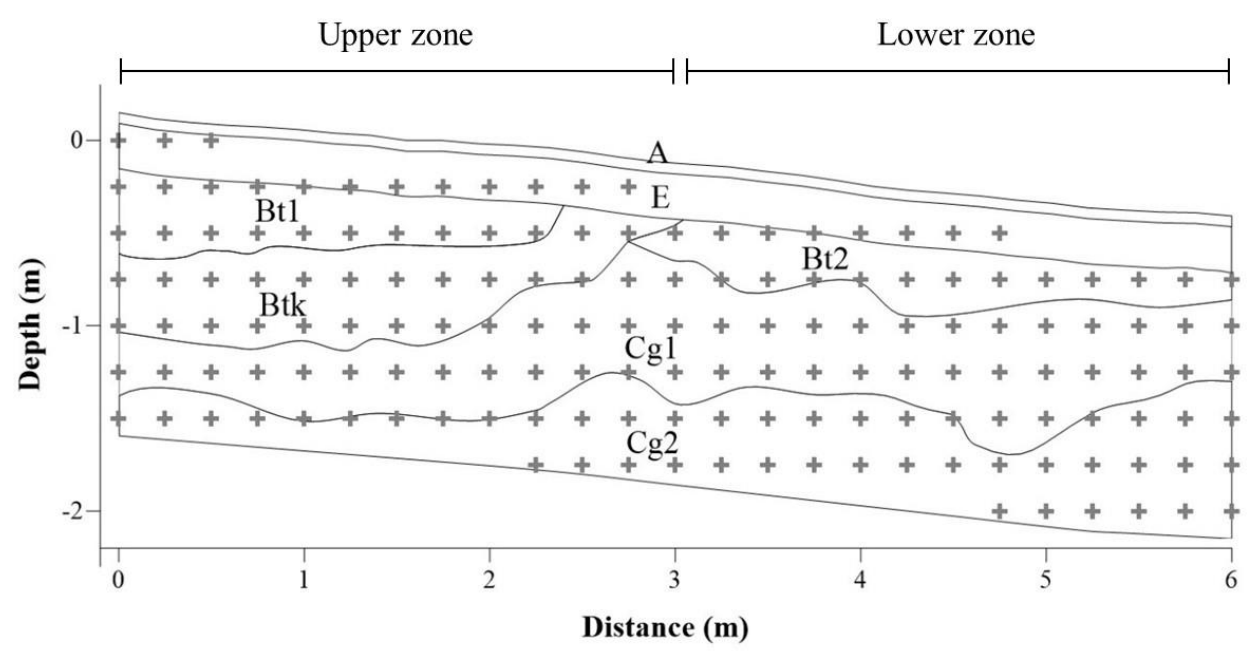

Fig. 3. Soils organization along the studied trench. Light continuous line shows horizons limits identified in the fieldwork, with Btk horizon presenting a basin shape. Crosses identify the grid of sampled points.

\subsection{Laboratory analyses}

The air-dried inorganic fine earth particle size analysis was carried out using the hydrometer method (USDA, 1996) for clay and silt. After drying, the sand was sieved into 5 sizes and weighed. The sand sizes were split into very coarse $(1-2 \mathrm{~mm})$, coarse $(0.5-1 \mathrm{~mm})$, medium $(0.25-0.5)$, fine $(0.125-0.25 \mathrm{~mm})$ and very fine $(0.125-0.05 \mathrm{~mm})$. The potential acidity $(\mathrm{H}+\mathrm{Al})$ and exchangeable 
cations $\left(\mathrm{Ca}^{2+}, \mathrm{Mg}^{2+}, \mathrm{K}^{+}\right.$and $\left.\mathrm{Na}^{+}\right)$were determined through ion displacement, as described by Embrapa (1997). $\mathrm{Ca}^{2+}$ and $\mathrm{Mg}^{2+}$ were extracted with $1 \mathrm{~N} \mathrm{KCl}, \mathrm{K}^{+}$and $\mathrm{Na}^{+}$with $0.0125 \mathrm{~mol} \mathrm{~L}^{-1} \mathrm{H}_{2} \mathrm{SO}_{4}$ $+0.05 \mathrm{~mol} \mathrm{~L}^{-1} \mathrm{HCl}$, and $\mathrm{H}^{+}+\mathrm{Al}^{3+}$ with a $0.5 \mathrm{~mol} \mathrm{~L}{ }^{-1}$ calcium acetate solution at $\mathrm{pH}$ 7.0. $\mathrm{Ca}^{2+}$ and $\mathrm{Mg}^{2+}$ contents were determined by atomic absorption spectroscopy, $\mathrm{K}^{+}$and $\mathrm{Na}^{+}$by flame photometry and $\mathrm{H}^{+}+\mathrm{Al}^{3+}$ by complexometric titration. The Effective Cation Exchange Capacity was calculated as: $\mathrm{CEC}=\mathrm{Ca}^{2+}+\mathrm{Mg}^{2+}+\mathrm{K}^{+}+\mathrm{Na}^{+}+\mathrm{H}^{+}+\mathrm{Al}^{3+}$ (Equation 1), the base saturation as:

$\mathrm{BS}=\mathrm{Ca}^{2+}+\mathrm{Mg}^{2+}+\mathrm{K}^{+}+\mathrm{Na}^{+} \times 100 / \mathrm{CEC}$ (Equation 2), and each cation was presented by its equivalent fraction of CEC, calculated as $\mathrm{E}_{\text {cation }}=$ cationx100/CEC ( $\mathrm{E}_{\mathrm{Ca}}, \mathrm{E}_{\mathrm{Mg}}, \mathrm{E}_{\mathrm{K}}, \mathrm{E}_{\mathrm{Al}}$ and $\mathrm{E}_{\mathrm{Na}}$, the latter also known as ESP) (Equation 3).

OSL dating was performed by the LDCPS Ltd laboratory in São Paulo, Brazil, using the singlealiquot regenerative dose method (SAR) (Wallinga et al., 2000). In addition, undisturbed blocks were collected from Btk, Bt and Cg horizons, which were impregnated with an acetone-diluted polyester resin (Arazyn ${ }^{\circledR} 1.0$ - Ashland) after air dehydration, and vertical thin sections $(1,8 \times 50 \times 70 \mathrm{~mm})$ were made and described according to Bullock et al. (1985) and Stoops (2003).

In order to appreciate the geochemical profile of the soil solution and its variations along the trench, and due to the difficulty in directly collecting free soil solutions in the vadose zone, saturated extracts were obtained from the soil samples. The saturation point of the sample was estimated in accordance with the criteria established by USDA (1996). Subsequently, the saturation solutions were extracted under vacuum conditions (Pansu and Gautheyrou, 2006). Anions $\left(\mathrm{Cl}^{-}, \mathrm{Br}^{-}, \mathrm{SO}_{4}{ }^{2-}, \mathrm{F}^{-}, \mathrm{NO}_{3}^{-}\right.$, $\left.\mathrm{NO}_{2}{ }^{-}, \mathrm{PO}_{4}{ }^{3-}\right)$ and cations $\left(\mathrm{Li}^{+}, \mathrm{Na}^{+}, \mathrm{K}^{+}, \mathrm{Ca}^{2+}, \mathrm{Mg}^{2+}, \mathrm{Al}^{3+}, \mathrm{Fe}, \mathrm{Si}^{4+}, \mathrm{Mn}, \mathrm{NH}_{4}^{+}\right.$) were determined using High-Pressure Liquid Chromatography (HPLC). The soil electrical conductivity (EC) was measured in the saturated paste extract from 121 samples.

\subsection{Data modelling}

Analytical results were used in geostatistical analyses and the spatial variability patterns were used for interpolation of each soil attribute by standard kriging in order to trace their distribution along the trench. Principal components analyses (PCA) were carried out through diagonalization of the correlation matrix to identify and rank the major factors of variability along the trench. A first analysis, $\mathrm{PCA}_{1}$, was carried out on 121 observations using the exchange complex and field $\mathrm{pH}$ as variables $\left(\mathrm{E}_{\mathrm{Ca}}, \mathrm{E}_{\mathrm{Mg}}, \mathrm{E}_{\mathrm{Na}}, \mathrm{E}_{\mathrm{K}}, \mathrm{E}_{\mathrm{Al}}, \mathrm{BS}, \mathrm{CEC}, \mathrm{EC}, \mathrm{pH}\right)$. A second analysis, $\mathrm{PCA}_{2}$, was performed on the chemical data from the saturated extracts, using 19 variables $\left(\mathrm{EC}, \mathrm{Li}^{+}, \mathrm{Na}^{+}, \mathrm{K}^{+}, \mathrm{Ca}^{2+}, \mathrm{Mg}^{2+}, \mathrm{Al}^{3+}, \mathrm{Fe}\right.$, $\mathrm{Si}^{4+}, \mathrm{Mn}, \mathrm{NH}_{4}^{-}, \mathrm{H}^{+}, \mathrm{Cl}^{-}, \mathrm{Br}^{-}, \mathrm{SO}_{4}{ }^{2-}, \mathrm{F}^{-}, \mathrm{NO}_{3}{ }^{-}, \mathrm{NO}_{2}{ }^{-}, \mathrm{PO}_{4}{ }^{3-}$, Clay content) and 121 observations. In order to observe element behavior as the medium becomes more concentrated, a concentration diagram was produced based on the results of saturated extracts, using $\mathrm{Na}^{+}$as conservative element.

\section{Results}

The spatial distribution of $\mathrm{EC}_{\mathrm{EM}}$ values matches with paleochannel-paleolevee complex boundaries, where higher values are situated on the elevated landform and follow the east-west direction (Fig. 2). The soil in the whole trench is classified as Abruptic Stagnic Solonetz (Albic, Loamic, Cutanic, Magnesic, Hypernatric), according to WRB - World Reference Base for Soil Resources (IUSS, 2015), and as Aquic Natraqualf, according to Soil Taxonomy (Soil Survey Staff, 2014). However, based on soil morphology, the trench was divided into two parts, namely upper and lower zones (Fig. 3). In the upper zone, the sequence of horizons is $\mathrm{A}, \mathrm{E}, \mathrm{Bt} 1, \mathrm{Btk}, \mathrm{Cg} 1$ and $\mathrm{Cg} 2$. Btk and $\mathrm{Cg} 1$ are seasonally saturated, especially during flooding peaks. In the lower zone, Bt1 and Btk disappear and are replaced by $\mathrm{Bt} 2$, giving rise to a sequence of $\mathrm{A}, \mathrm{E}, \mathrm{Bt} 2, \mathrm{Cg} 1$ and $\mathrm{Cg} 2$ horizons. The lower zone is entirely saturated by water during the flooding period. The transition between the upper and lower zones is marked by wavy topography between Btk and Bt2, where the former rises above the latter, and by a color contrast, which is reddish at Btk and palest at Bt2 (Fig. 3).

The A horizon is dark brown (7.5YR 3/2), has a sandy loam texture and granular structure. Below, the E horizon is light brownish gray (10YR 6/2) and single grain but is loamy sand in the upper zone 
and sandy loam in the lower zone. The underlying Bt1 and Bt2 horizons have loamy texture and prismatic structure that breaks into subangular blocks, although the latter is more yellowish (brown, 10YR 5/4) than the former (brown, 7.5YR 4/2). The Btk is brown (7.5YR 5/4), sandy loam and prismatic, with a basin-shaped transition to the underlying horizon. It has abundant yellowish and reddish mottles and both macro and micromorphology features that indicate calcite precipitation in fissures, between peds or in ancient root channels (Fig. 4a, b). The calcite nodules are impregnated with clay minerals and iron oxides, have weak or powdery consistency and do not contain an internal cortex (Fig. 4b). The deepest horizons, Cg1 and Cg2, are brown (7.5YR 5/2) and massive, differing mainly in texture, which is loamy sand to sandy clay loam in the former and sandy loam in the latter.

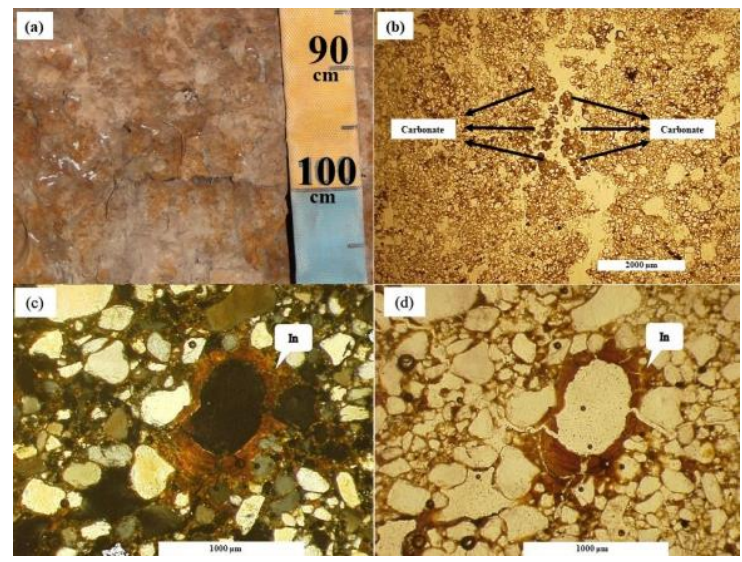

Fig. 4. Btk horizon: (a) Calcite concentrations in the profile scale (whitish spots); (b) Photomicrograph showing nodules at $12 \times$ magnification in plane polarized light (PPL). Arrows indicate the preterit carbonate nodules at former soil cracks. (c,d) Photomicrographs showing pore coatings and infillings (In) with strong orientation (c - crossed polarized light - XPL and d - PPL).

Based on the grid samples, total sand varies between 130 and $910 \mathrm{~g} \mathrm{~kg}^{-1}$, but $75 \%$ of the values are larger than $500 \mathrm{~g} \mathrm{~kg}^{-1}$, with higher concentrations in the $\mathrm{A}, \mathrm{E}$ and $\mathrm{Cg}(1,2)$ horizons (Fig. 5b). Among the sand particles, fine sand dominates in the entire trench, ranging between 67 and $812 \mathrm{~g} \mathrm{~kg}^{-1}$. Additionally, regions of fine sand, randomly disposed in the matrix and without regular shape, occur at several places in the bottom part of the trench; one of which was chosen for OSL dating, revealing a date of approximately $21.5 \pm 6.0 \mathrm{kyr}^{1}$. The silt and clay amounts vary from 3 to $492 \mathrm{~g} \mathrm{~kg}^{-1}$ and from 38 to $388 \mathrm{~g} \mathrm{~kg}^{-1}$, respectively, both being concentrated mainly in the Bt horizons (Bt1, Bt2 and Btk) (Fig. 5a). The micromorphology data reveal that the increase in clay content in the lower zone is partially a result of illuvial features, which occur as continuous and strongly oriented pore coatings and infillings (Fig. 4c, d).

The $\mathrm{pH}-\mathrm{H}_{2} \mathrm{O}$ varies widely along the trench, changing from very strongly acidic (4.6) to strongly alkaline (9.1). It clearly decreases from higher to lower topographical positions. The values are between 4.9 and 9.1 in the upper zone, with $60 \%$ of the grid samples higher than 7.0 , and between 4.7 and 6.6 in the lower zone, with $76 \%$ of the values lower than 5.6. The highest values are concentrated in horizons Bt1 and Btk, whereas the lowest values are in $\mathrm{Cg} 2$ (Fig. 5c). The EC is low in the entire trench, ranging between 0.03 and $0.61 \mathrm{dS} \mathrm{m}^{-1}$, with higher values in the upper zone, especially in the Btk horizon (Fig. 5d).

The Cation Exchange Capacity (CEC) changes from 1.65 to $13.42 \mathrm{cmol}_{\mathrm{c}} \mathrm{kg}^{-1}$ in the trench, with higher values in the upper zone, specifically in the Bt and Btk horizons (generally above $9.0 \mathrm{cmol}_{\mathrm{c}}$ $\mathrm{kg}^{-1}$ ) (Fig. 5e). Base saturation (BS) ranges between 39 and $100 \%$ but is generally higher than $90 \%$ in the upper zone and lower than $90 \%$ in the lower zone, with the lowest values in $\mathrm{Cg} 2$ (Fig. 5f). The

\footnotetext{
${ }^{1} \mathrm{U}$, Th and $\mathrm{K}$ values, used for dose rate calculations, are $2.537 \pm 1.288 \mathrm{ppm}, 3.953 \pm 0.142 \mathrm{ppm}$ and $0,511 \pm 0.074 \%$, respectively. The annual dose rate is $1700 \pm 400 \mu \mathrm{Gy} / \mathrm{year}$ and the equivalent dose is $37.10 \mathrm{~Gy}$.
} 
most abundant exchangeable cations in the upper zone are $\mathrm{Mg}^{2+}$ in the $\mathrm{A}$ and $\mathrm{E}$ horizons and $\mathrm{Na}^{+}$in the Bt, Btk, $\mathrm{Cg} 1$ and $\mathrm{Cg} 2$ horizons, whereas in the lower zone $\mathrm{Mg}^{2+}$ dominates the whole profile, with the exception of the deepest horizon $(\mathrm{Cg} 2)$, which is dominated by exchangeable $\mathrm{Al}^{3+}+\mathrm{H}^{+}($Fig. $5 \mathrm{~g})$. The ESP $\left(\mathrm{E}_{\mathrm{Na}}\right.$ ) ranges from 0 to $50 \%$, but clearly varies laterally, $70 \%$ of the samples being higher than $40 \%$ in the upper zone and $85 \%$ of the samples lower than $40 \%$ in the lower zone. Btk and $\mathrm{Cg} 2$ present the highest and lowest values of the profile, respectively (Fig. 5h).
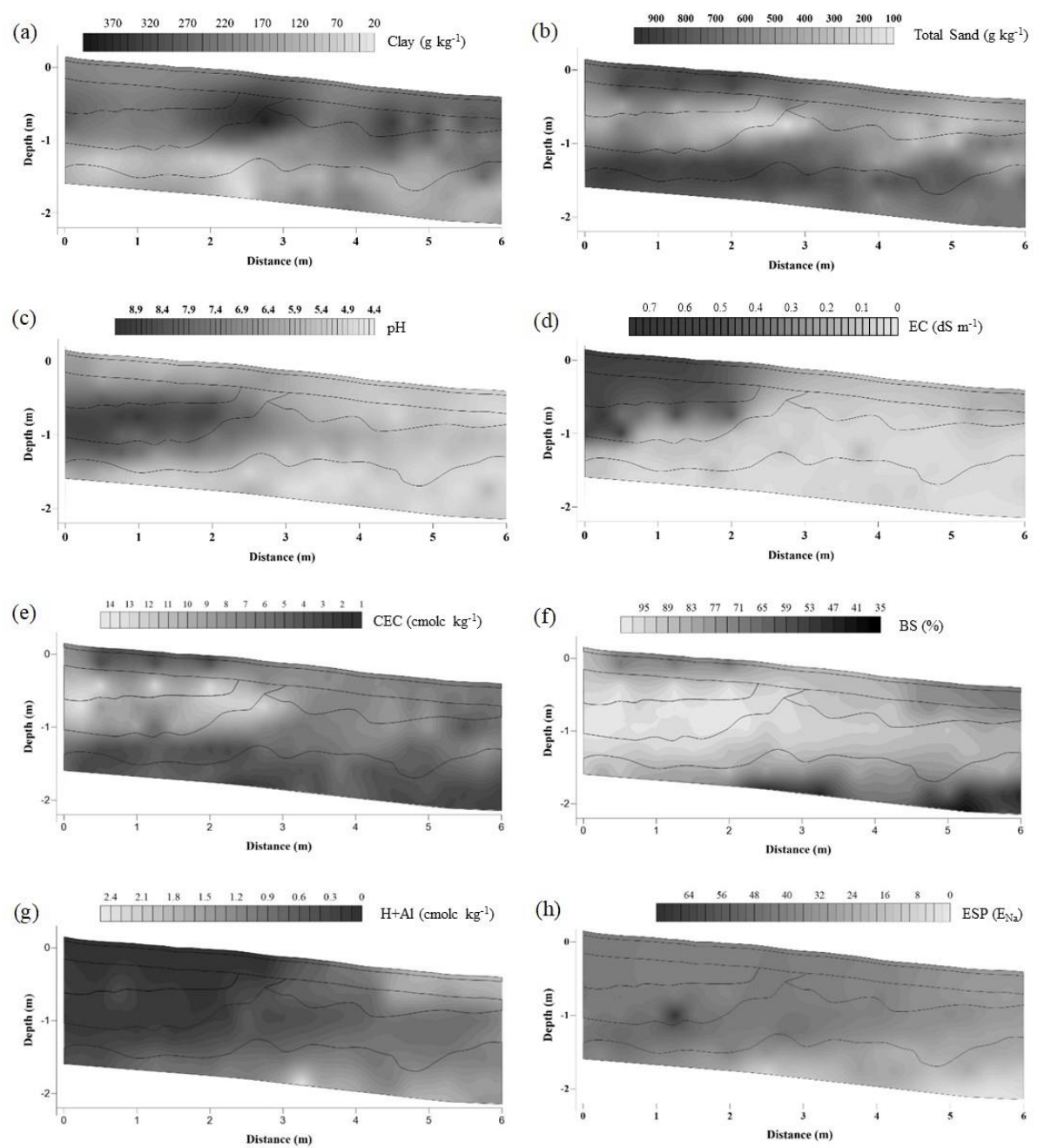

Fig. 5. Spatialization of clay contents (a), total sand (b), $\mathrm{pH}(\mathrm{c})$, Electrical Conductivity (EC - d), cation exchange capacity $(\mathrm{CEC}-\mathrm{e})$, bases saturation $(\mathrm{BS}-\mathrm{f})$, exchangeable $\mathrm{H}+\mathrm{Al}(\mathrm{g})$ and Equivalent fraction of $\mathrm{Na}+$ in CEC (ENa or ESP - h).

Among the saturated extract ions, $\mathrm{Na}^{+}$and $\mathrm{Ca}^{2+}$ are the main cations and alkalinity the main anion in the samples of the trench grid. Values of $\mathrm{Na}^{+}$vary from 0.02 to $9.71 \mathrm{meq} \mathrm{L}^{-1}$ and are usually higher in the upper zone, whereas $\mathrm{Ca}^{2+}$ varies from 0.20 to $3.09 \mathrm{meq} \mathrm{L}^{-1}$ and is generally higher in the lower zone. Samples with higher $\mathrm{Ca}^{2+}$ values are mostly from greater depths, especially $\mathrm{Cg} 1$ and $\mathrm{Cg} 2$ horizons. Alkalinity values are between 0.42 and $10.26 \mathrm{meq} \mathrm{L}^{-1}$, the highest values occurring among anions and all ions in the whole trench. The concentration diagram shown in Fig. 6, which uses $\mathrm{Na}^{+}$ as the concentration factor (conservative element), confirms that alkalinity is the major ion during concentration, tending to rise until concentration factor 10. Calcium tends to follow solution concentration only until concentration factor 6 , and over this point the calcite reaches its solubility product constant $\left(\mathrm{K}_{\mathrm{sp}}\right)$ and then precipitates. 


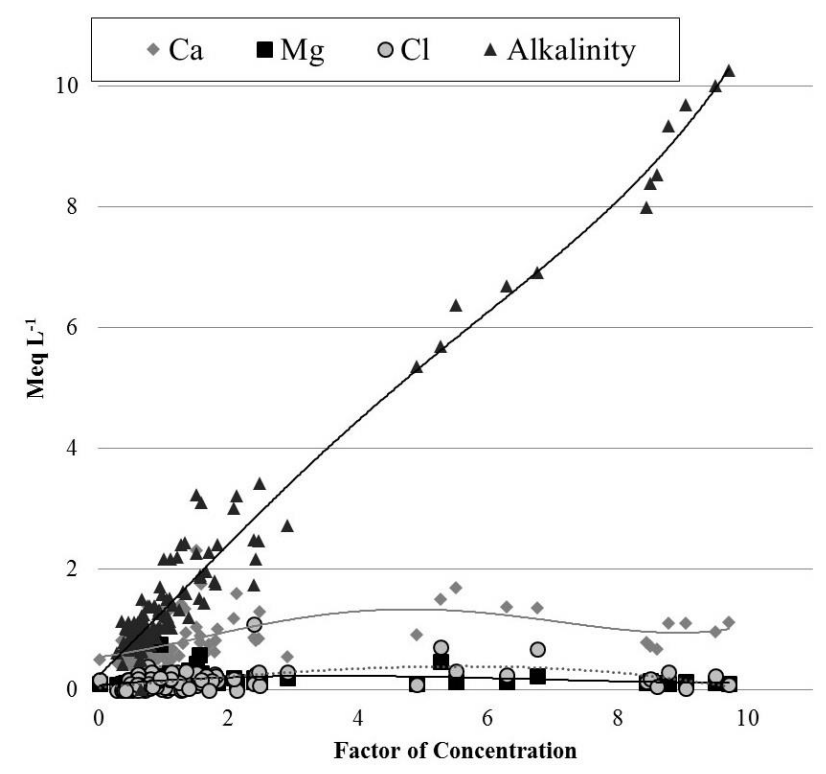

Fig. 6. Concentration diagram based on saturated extract results from 121 samples collected in the trench. Alkalinity is higher than $\mathrm{Ca} 2+$, driving the solution through an alkaline-sodic pathway.

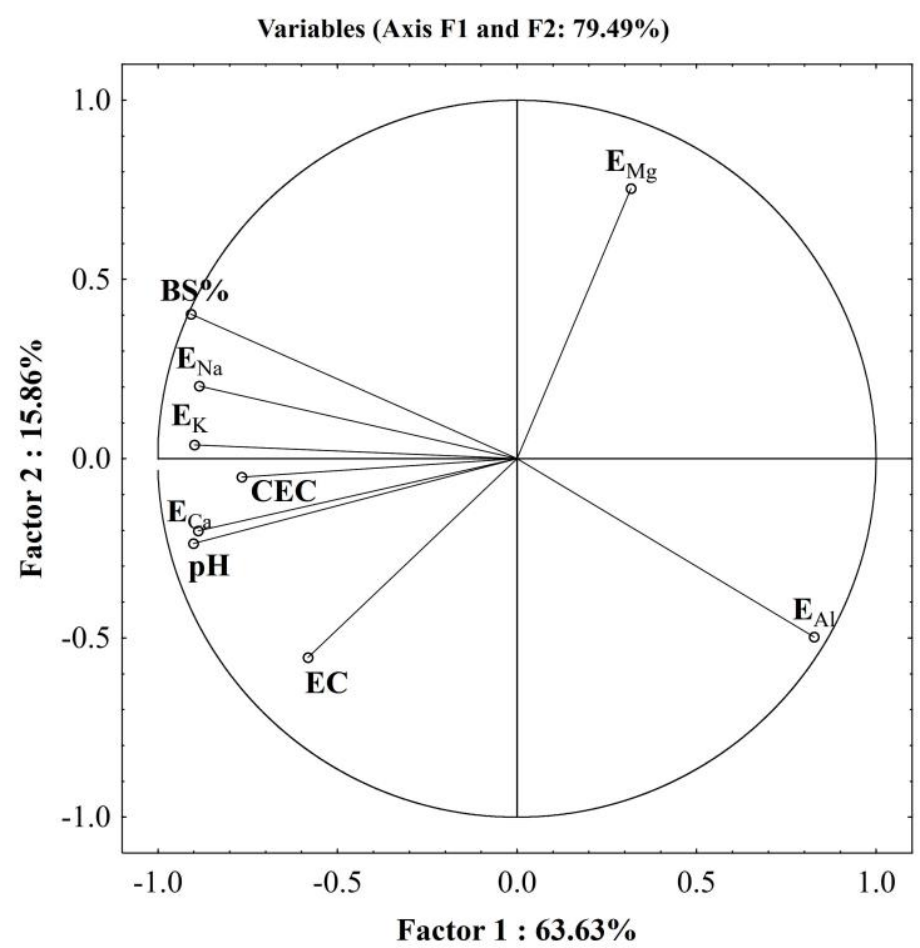

Fig. 7. Variables on scores plot F1-F2 of PCA1 based on cation exchange complex, pH and EC from 121 samples collected in the trench.

$\mathrm{PCA}_{1}$ performed on the soil exchangeable complex dataset revealed two principal components, $\mathrm{F} 1$ and F2 (Fig. 7), which together account for $79.49 \%$ of the total variance $(63.63 \%$ and $15.86 \%$, respectively). Unlike the other variables, $\mathrm{E}_{\mathrm{Mg}}$ and $\mathrm{E}_{\mathrm{Al}}$ are positively scored to F1 (Fig. 7) (0.32 and 0.83 , Table 2). Fig. 8 shows two major groups of variables in $\mathrm{PCA}_{2}$, performed on the saturated paste extract. $\mathrm{Fe}, \mathrm{Mn}, \mathrm{SO}_{4}{ }^{2-}$ and $\mathrm{Mg}^{2+}$ are in the first group, consisting of redox-sensitive variables. $\mathrm{Na}^{+}$, $\mathrm{EC}, \mathrm{F}^{-}$and $\mathrm{Si}^{4+}$ are in the second group, which is a pattern commonly associated with salt-affected soil processes through soil solution concentration. The $\mathrm{PCA}_{2}$ highlighted three important axes (U1, U2 and U3) accounting for $28.6 \%, 16.0 \%$ and $9.0 \%$ of total variation, respectively (Table 1). Scores plotted for U1-U2 (Fig. 8a), display the opposition between $\mathrm{H}^{+}$and the first group of variables $\left(\mathrm{Mg}^{2+}\right.$, 
$\mathrm{Fe}, \mathrm{Al}^{3+}, \mathrm{Mn}$ and $\left.\mathrm{SO}_{4}{ }^{2-}\right)$ along axis $\mathrm{U} 1$, and between $\mathrm{H}^{+}$and the second group of variables $\left(\mathrm{Na}^{+}, \mathrm{EC}\right.$, $\mathrm{F}^{-}$and $\mathrm{Si}^{4+}$ ) along axis $\mathrm{U} 2$. The $\mathrm{U} 3$ axis has high positive loads for $\mathrm{NO}_{3}{ }^{-}$and $\mathrm{Br}^{-}$, whereas it has moderate negative loads for $\mathrm{NO}_{2}^{-}, \mathrm{F}^{-}$, and clay (Fig. 8b).
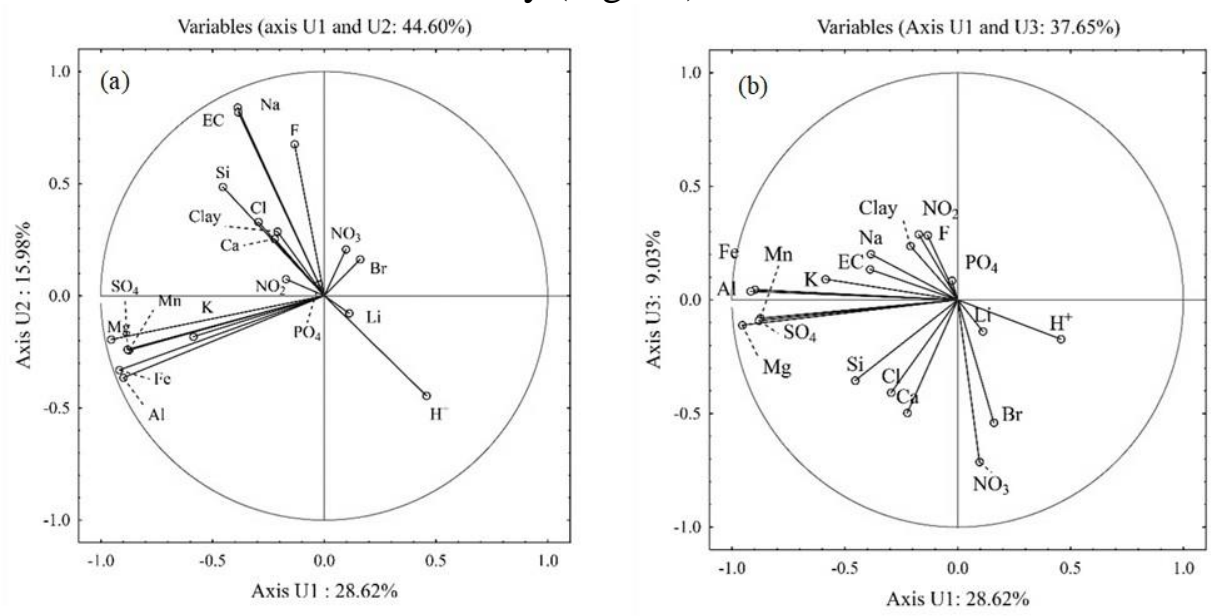

Fig. 8. PCA2 based on saturated extract and clay content from 121 samples collected in the studied trench; a) First factorial plan is composed by U1-U2 showing the redox as major process and salinity processes as secondary processes. b) Second factorial plan is composed by U1-U3, pointing the redox process in weak anoxic condition.

\section{Discussion}

\subsection{Ancient sedimentation and textural contrasts}

The occurrence of Bt horizons and the concentration of clay and silt fractions along a similar vertical position through the whole trench (Fig. 3; 5a) suggest horizontal homogeneity and vertical heterogeneity of the parent material, in agreement with sedimentological stratification. As exposed in item 2.2 (Environmental Settings), the study area is in the São Lourenço megafan, especially in a mapping unit that includes paleochannel-paleolevee complexes (Nascimento, 2012), suggesting that the fluvial sedimentary processes in the fan is responsible for these textural contrasts.

The sandy sediments occurring in higher depths of the studied trench, which are the parent materials of the $\mathrm{C}$ horizons $(\mathrm{Cg} 1, \mathrm{Cg} 2)$, were likely deposited in a paleochannel and its associated paleolevee (Fig.10a). The deposits in the main channel are generally coarser than those deposited in the alluvial plain because of the higher energy of the river flow if compared with the flooding (Nichols, 2009). River levees also tend to have coarser sediments because of the relatively high velocity of the flow when it overpasses the river margin and the subsequent loss of energy and deposition of these sediments in the alluvial plain, near the main channel (Asselman and Middelkoop, 1995; Cazanacli and Smith, 1998).

The shallower and finer horizons (Bt1, Bt2, Btk) likely developed from silt and clay-enriched sediments deposited later, in lentic environments (Fig. 10b). The higher EC EM (Fig. 2) and EC values (Fig. 5d), generally associated with these horizons, are in accordance with the direction and boundaries of the paleochannel-paleolevee complex, suggesting that the finer particles were deposited in an ancient river that was abandoned by avulsion. This explanation is corroborated by the aerial view provided in Fig. 9, which shows a main paleochannel and a smaller and secondary paleochannel that likely represent an abandoned river. When the stream breaks the riverbank in the point of avulsion, the river assumes a new direction and leaves a non-active channel, which becomes a lowenergy zone. The fine sediments of these abandoned rivers come mainly from the water that remained in the channel and from the flooding of the new river (Nichols, 2009).

The abandonment of channels by avulsion processes, such as observed in the study area (Fig. 9), has been registered in fluvial systems around the world, including the Cumberland marshes in Canada (Morozova and Smith, 1999), the Rhine-Meuse delta in The Netherlands (Stouthamer, 2001; Tornqvist, 1994) and alluvial megafans such as the Okavango in Botswana (McCarthy et al., 1992), 
Kosi and Gandak in India (Sinha and Friend, 1994) and Taquari and Cuiabá in the Pantanal, Brazil (Assine, 2005; Makaske et al., 2012; Pupim et al., 2017). Although the frequency of river avulsion in alluvial systems was estimated between 500 and 5000 years by Tornqvist (1994) in the RhineMeuse delta, it seems that it is significantly more frequent in the Kosi, Gandak and Taquari megafans, where this process has been recurrent in one or a few decades in the last centuries (Assine, 2005; Sinha and Friend, 1994).

The sandy loam upper horizons (A, E), above the finer horizons, were likely formed by local erosion processes, where paleolevee coarser sediments in the abandoned channel boundaries were partially transported to the center of the lake, burying the finer sediments.

The dating of $21.5 \pm 6.0 \mathrm{kyr}$ in a deep zone of the trench suggests that paleochannel-paleolevee deposition occurred in the Late Pleistocene, after the climate became more humid in the region, at approximately 19.5 kyr BP (Whitney et al., 2011).

Table 1. Eigenvalue and percentage value of each factorial axis on $\mathrm{PCA}_{2}$, where data was yielded from saturation extract, suggesting that $\mathrm{U} 1, \mathrm{U} 2$ and $\mathrm{U} 3$ are useful to explain the different biogeochemical process, performing together $53.6 \%$ of total variation.

\begin{tabular}{lcccccccccc}
\hline Factorial axis & 1 & 2 & 3 & 4 & 5 & 6 & 7 & 8 & 9 & 10 \\
\hline Singular value & 5.44 & 3.04 & 1.72 & 1.49 & 1.25 & 1.04 & 0.92 & 0.87 & 0.77 & 0.70 \\
Variance (\%) & 28.6 & 16.0 & 9.0 & 7.8 & 6.6 & 5.5 & 4.8 & 4.6 & 4.1 & 3.67 \\
Cumulated variance (\%) & 28.6 & 44.6 & 53.6 & 61.4 & 68.0 & 73.5 & 78.3 & 82.9 & 87.0 & 90.66 \\
\hline
\end{tabular}

\subsection{Past $\mathrm{Na}^{+}$accumulation in depression zones}

The soils developed on these sediments are mostly characterized by ESP of over $20 \%$, showing high sodium accumulation, which originated from concentration of solutions in an evaporative environment. Chemical data from the saturated extract and the concentration diagram (Fig. 6) suggest that the evaporative evolution of the solutions had occurred through an alkaline-sodic pathway, inasmuch as it requires alkalinity values equivalent to or higher than $\mathrm{Ca}^{2+}$ (Droubi et al., 1980). This process is commonly described in other wetlands submitted to high evaporation rates, such as the Okavango delta in Botswana, especially in lakes and seasonally inundated floodplains (Sawula and Martins, 1991; Mackay et al., 2011; Meier et al., 2015).

Table 2. $\mathrm{PCA}_{1}$ singular values of exchangeable complex attributes within each factorial axis, for 121 samples in a trech with $6 \mathrm{~m}$ large and $2 \mathrm{~m}$ deep, collected on regular grid $(0.25 \mathrm{~m} \times 0.25 \mathrm{~m})$.

\begin{tabular}{lcc}
\hline & $\mathrm{F} 1$ & $\mathrm{~F} 2$ \\
\hline $\mathrm{pH}_{\mathrm{H} 2 \mathrm{O}}$ & -0.90 & -0.24 \\
$\mathrm{CEC}$ & -0.77 & -0.05 \\
$\mathrm{BS} \%$ & -0.91 & 0.40 \\
$\mathrm{E}_{\mathrm{Na}}$ & -0.89 & 0.20 \\
$\mathrm{E}_{\mathrm{Ca}}$ & -0.89 & -0.20 \\
$\mathrm{E}_{\mathrm{Mg}}$ & 0.32 & 0.75 \\
$\mathrm{E}_{\mathrm{K}}$ & -0.90 & 0.04 \\
$\mathrm{EC}$ & -0.58 & -0.55 \\
$\mathrm{E}_{\mathrm{Al}}$ & 0.83 & -0.50 \\
\hline
\end{tabular}

During the concentration, when the solution reaches the $\mathrm{K}_{\mathrm{sp}}$ of calcite, most of the $\mathrm{Ca}^{2+}$ is consumed in mineral precipitation, causing $\mathrm{Ca}^{2+}$ desorption and $\mathrm{Na}^{+}$adsorption in the exchangeable complex. This sodium accumulation in soils, known as solonization, results in slight alkalinity consumption and a subsequent increase in alkalinity levels as the medium becomes more concentrated. Soil $\mathrm{pH}$ reaches values above 8.5, as observed mainly in the studied Btk horizon, which is attributed to $\mathrm{OH}^{-}$release to the solution through sodium hydrolysis and sodium carbonate reactions 
(Bohn et al., 2001; McBride, 1994). In the study area, the São Lourenço river and its inundation waters have much higher alkalinity values than the sum of $\mathrm{Ca}^{2+}$ and $\mathrm{Mg}^{2+}$ (Rezende Filho et al., 2012), producing the alkaline-sodic pathway when subject to concentration.

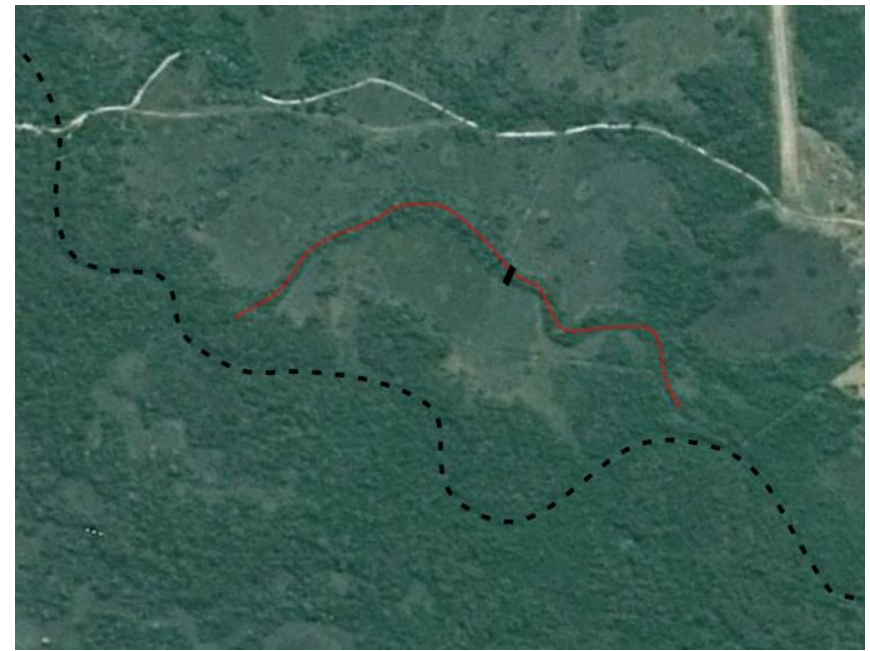

Fig. 9. Geomorphological setting of studied site. Black dashed line highlights subsequent river channel, after an avulsion. Red dashed line shows the abandoned channel. Black Rectangle indicates the trench opened in the paleochannel-paleolevee complex. (For interpretation of the references to color in this figure legend, the reader is referred to the web version of this article.)

The Pantanal wetland is marked by high evapotranspiration rates and an annual water deficit, providing conditions for present-day alkaline-sodic solution development. In the southern Pantanal (Nhecolândia sub-region) the surface and subsurface waters are being concentrated in alkaline-saline lake depressions through evaporation (Barbiero et al., 2002; Furquim et al., 2008; Furquim et al., 2010). However, in the study area, the evolution of waters through alkaline-sodic pathway and soil solonization apparently occurred in past environments. The micromorphology revealed that the calcite nodules occurring in Btk present many fissures, weak or powdery consistency, indistinct cores and are located in major pores (Fig. 4). Calcite formed in concentration environments has a dense cortex and is located in soil microvoids (PiPujol and Buurman, 1994), which suggests that the nodules of the study area are not in equilibrium with the current soil solution, being subjected to unstable conditions and to dissolution and remobilization (Fig. 4).

It is probable that the sodium accumulation in northern Pantanal was more intense in ancient rivers abandoned by avulsion, because the finer horizons tend to present the highest $\mathrm{pH}$ and ESP of the trench. The occurrence of diatoms that are typical of lacustrine environments in thin sections of sodic horizons near the study area corroborates the sodium accumulation in lentic and depressed environments (Oliveira Junior, 2017a). These environments likely allowed the incoming of solutes and prevented leaching, permitting their evaporative concentration during drought periods and the concomitant precipitation of carbonates. It is also possible the neoformation of clay minerals in these environment, such as observed by Furquim et al. (2010) in the current saline lakes of southern Pantanal, increasing the amount of clay particles in the finer sediments deposited in the abandoned channel.

According to Whitney et al. (2011), based on pollen and diatom of lake sediments in the northern Pantanal, from 19.5 kyr BP until the Holocene/Pleistocene transition (12.2 kyr BP), the region was marked by an increase in humidity, with the presence of inundation-tolerant species at the seasonally exposed margins of the lake. During the Holocene, moderate drought in the Pantanal and its vicinity was observed from 10 to $3 \mathrm{kyr}$ BP by Whitney et al (2011), from 5.3 to $2.6 \mathrm{kyr}$ BP by McGlue et al. (2012), using radiocarbon dating, and from 3.8 to $2.6 \mathrm{kyr}$ by Bertaux et al. (2002), using ${ }^{230} \mathrm{Th} /{ }^{234} \mathrm{U}$ dating on speleothems. The $\mathrm{Na}^{+}$accumulation in the study area probably occurred during these 
moderate droughts, when the flood levels tended to remain intermediary (Whitney et al., 2011), which is ideal for the influx of floodwater and evaporative concentration, without soil leaching by excess freshwater. Thus, the salt accumulation in the study area seems to have occurred mainly in past drier periods of the Holocene.

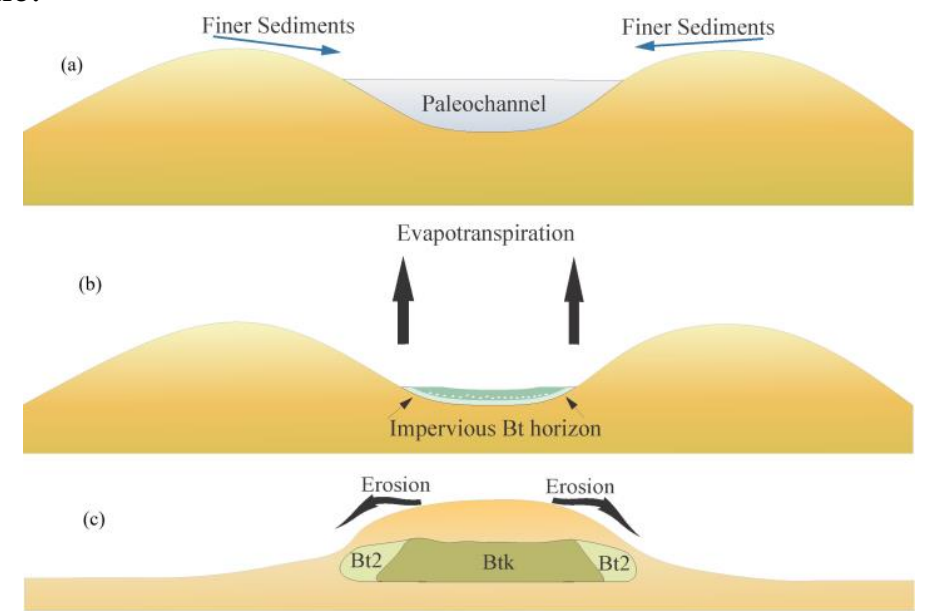

Fig. 10. Geomorphological and pedological events in abandoned channel: (a) successive cycles of floodwater and fine sediments input; (b) Lentic environment leading to clay accumulation; (c) the remaining of salt affected soil in the upper part of landscape due Btk morphological control and lateral transformation of Btk in Bt2 horizon, result of solodization driven by floodwater in current framework. (Adapted from Oliveira Junior et al., 2017a.)

\subsection{Erosion of the paleochannel-paleolevee complex, current topography and pedogenetic processes}

Alluvial fans are formed by current and ancient depositional lobes, which are sedimentary zones originating from active deposition of a drainage system (Zani et al., 2009). The distributary rivers dominate in active lobes, but the ancient lobes are not currently zones of intense sedimentation, with a significant occurrence of tributary rivers and erosional processes (Schumm, 1977). According to Assine et al. (2014), abandoned lobes of the São Lourenço megafan have been dissected by modern tributaries, small intermittent rivers, producing erosional features over previous aggradational landforms, such as distributary paleochannels and associated paleolevees.

The studied trench is located in an ancient lobe of the São Lourenço megafan that has experienced intense and regional erosion (Nascimento, 2012), which has probably been magnified in the more humid conditions of the last 2600-3000 years (Bertaux et al., 2002; Whitney et al., 2011; McGlue et al., 2012). Thus, continuous elevated zones formed by paleochannels-paleolevees have been destroyed, connecting the flood drainage, which favors leaching and prevents $\mathrm{Na}^{+}$accumulation through evaporative concentration (Nascimento et al., 2015; Oliveira Junior et al., 2017a, 2017b). Consequently, greater sediment mobilization due to erosion occurred in the sandy areas of the paleochannel-paleolevee complexes, leaving the finer (silty/clayey) and more resistant areas in discontinuous narrow topographical highs (Fig.10c).

ESP greater than $15 \%$ and EC lower than $4 \mathrm{dS} \mathrm{m}^{-1}$ along the whole studied trench reveals the presence of Sodic Soils (Solonetzes) in both the upper and lower zones (USSL Staff, 1954). As previously indicated, evolution of the solutions in an alkaline-sodic pathway triggered soil solonization, especially during drier Holocene climates. However, a distinction in chemical parameters is currently observed between the upper and lower zone of the studied trench, the latter clearly presenting lower values of $\mathrm{pH}, \mathrm{CEC}$, BS and ESP and higher values of exchangeable $\mathrm{H}^{+}+$ $\mathrm{Al}^{3+}$. These data show that solonization has gradually been replaced by solodization in the lower zone, a process characterized by significant leaching from the system, with loss of basic cations, especially $\mathrm{Na}^{+}$, accompanied by a decrease in $\mathrm{pH}$ and an increase in exchangeable $\mathrm{Al}$ and $\mathrm{H}^{+}$(Gedroiz, 1925; Fanning and Fanning, 1989). The identification of salt-affected parameters on the U2 axis, which 
explains only $15.98 \%$ of total variance, confirms that solonization is no longer of major importance in the study area.

The current inundation dynamic, induced by paleochannel-paleolevee erosion and the consequent production of the current topography, is responsible for higher leaching in the lower zone, since seasonal inundation reaches and significantly saturates this area every year. Thus, hydrological processes observed nowadays produce the main chemical differences along the trench, carrying cations and, consequently, decreasing $\mathrm{pH}, \mathrm{CEC}, \mathrm{BS}$ and PST, while increasing $\mathrm{H}^{+}$and $\mathrm{Al}^{3+}$ in the lower topographical areas. However, local scale hydrology likely aids the preservation of solonization in the upper zone, inasmuch as the presence of a basin-like Btk horizon with low permeability inhibits free drainage in the profile, isolating this part of the landscape from the diluted water of the floodplain and enabling relatively higher local evapotranspiration rates.

Furquim et al. (2017) observed a similar process around brackish lakes in the southern Pantanal (Nhecolândia sub-region), where solodization acts in lower zones, producing degraded Sodic soils, such as Solodized Solonetzes and Solods, whereas Solonetzes occur in the higher borders of the depression. According to these authors, solodization also occurs due to the inundation dynamics, which provide seasonal freshwater inflow into the lakes, forming intermittent waterflows between them during the inundation season. In our study area, however, the low advance of leaching has not yet enabled the formation of degraded Sodic soils in the lower zone, although it seems to be just a matter of time.

The oxidation-reduction of $\mathrm{Fe}^{3+}$ and $\mathrm{Mn}^{4+}$ in a highly anoxic environment, seems to be the major process in the study area nowadays, which is corroborated by the fact that the U1 axis accounts for most of the variation in $\mathrm{PCA}_{2}(28.62 \%)$. Longer water saturation, provoked by the seasonal flood, especially in the lower zone, triggers redox processes in the area. In the upper zone, the Btk horizon acts as a semi-permeable barrier, hampering rainwater drainage and favoring water saturation, analogous to an aquitard. Such conditions enable development of the anoxic environment, but to a lesser degree than in the lower zone, which is subject to flooding.

The variation of the $\mathrm{N}$ forms indicated by the $\mathrm{U} 3$ axis (Fig. 8b) ratifies the biological activity as one of the main transformation processes currently acting on the wetland soils. Its greatest expression occurs at a greater depth, immediately below the occurrence of the first factorial axis. The $\mathrm{N}$ transformation is also favored by higher clay content, which hinders the gas exchange and creates anoxic micro-sites, where $\mathrm{N}$ transformation occurs, explaining the large spatial variability observed in Fig. 8b.

Another process currently identified in the studied area is the local clay translocation, which is corroborated by the small presence of continuous strongly oriented pore coatings and infillings in the thin sections of the lower zone (Fig. 4c, d). The water movement provoked by saturation and desaturation during the rainy season and at the beginning of the dry season is probably responsible for local remobilization of the clay, which is primarily deposited in the area by sedimentary processes and/or clay authigenesis. ESP higher than $15 \%$ in the lower zone facilitates clay dispersion, with the consequent suspension and transport of colloids (Rengasamy and Sumner, 1998). Silt and clay particles are concentrated at the same depths in the study trench, which suggests that deposits of previous layers enriched in fine fractions probably acted as a sieve, providing an obstacle to water penetration and triggering clay deposition, similar to that observed in an experiment of clay translocation performed by Bond (1986).

\section{Conclusions}

Sedimentological and geomorphological processes in modern alluvial fans are extremely dynamic, affecting soil genesis in short periods. The São Lourenço alluvial fan has had a complex sedimentological history since at least the Late Pleistocene, having been submitted to a typical alternation of intense sedimentation in an active lobe and erosion in abandonment lobes. Additionally, the alluvial fan has been subjected to climate change during this period, with alternating drier and 
more humid periods. These environmental conditions have been responsible for the formation of different landforms and soil mosaics in the study region.

Approximately $20 \mathrm{kyr}$ ago, a distributary river-levee complex was responsible for the sedimentation of coarser sediments in the study trench. Later, an avulsion event created an abandoned channel and permitted solute accumulation and deposition of finer sediments. Periods with a moderately dry climate during the Holocene likely triggered the formation of Sodic soils (Solonetzes) with textural contrasts within these abandoned channels through evaporative concentration. The posterior migration of the active sedimentary lobe to another region, which is an intrinsic characteristic of alluvial fan evolution, created an abandonment lobe affected by tributary river erosion.

Currently, the more clayey regions formed in the depression of the abandoned channel are now the higher landform due to higher resistance and the current limit of the flood level. Thus, the sodic environment formed under past condition persists in these areas. Their current occurrence on topographically higher lands is a reflection of the geological and geomorphological processes that affected the region in the past, which culminate in the landform degradation due to a more humid climate and intense erosive processes in the current hydrological frame.

This study shows that the formation of salt-affected soils may have a complex sedimentological history, especially in active sedimentary basins of tropical zones, and that topography cannot be readily interpreted as the formation conditions for salt-affected soils on higher landforms. Thus, the genesis of salt-affected soils on higher landforms, which seems to be poorly understood in many situations worldwide, should be carefully investigated in order to address their mechanisms of formation.

\section{Acknowledgments}

The authors wish to thank SESC Pantanal for the logistic support, Edward Layland for English revision.

\section{Funding:}

This work was supported by FAPESP for granting a PhD scholarship for the first (process 2011/11905-9 and 2013/17766-6) and third (process 2009/50422-3) authors and for the funds to carry out the research (process 2009/54372-0).

The CNPq also supported this work through grants given to the sixth and seventh authors and for the $\mathrm{PhD}$ scholarship granted to the fourth author.

\section{References}

Abrol, I.P., Yadav, J.S.P, Massoud, F.I., 1988. Salt-affected soils and their management. Soil Resources, Management and Conservation Service FAO Land and Water Development Division. FAO Soils Bulletin, Rome.

Abtahi, A., 1977. Effect of a saline and alkaline ground water on soil genesis in semiarid southern Iran. Soil Science Society of America Journal. 41, 583-588.

Abtahi, A., 1980. Soil Genesis as affected by topography and time in highly calcareous parent materials under semiarid conditions in Iran. Soil Sci. Soc. Am. J. 44, 329-336.

Alfonsi, R.R., Camargo, M.B.P., 1986. Condições climáticas para a região do Pantanal Matogrossense. Anais do $1^{\circ}$ Simpósio sobre Recursos Naturais e Sócio-Econômicos do Pantanal, Corumbá (MS), pp. 29-42.

Alvarenga, S., Brasil, A., Pinheiro, R., Kux, H., 1984. Estudo Geomorfológico Aplicado à Bacia do Alto Rio Paraguai e Pantanais Matogrossenses. Boletim Técnico Projeto Radambrasil- Série Geomorfologia. 1 (187 p.). 
Alvarez, C.A., Stape, J.L., Sentelhas, P.C., Gonçalves, J.L.M, Sparovek, G. (2013) Koppen’s climate map for Brazil. Meteorologische Zeitschrift. 22, 711-728.

Asselman, N.E.M; Middlekoop, H., 1995. Floodplain sedimentation: quantities, patterns and process. Earth surface processes and landforms. 20, 481-499.

Assine, M. L., 2005. River avulsions on the Taquari megafan, Pantanal wetland, Brazil. Geomorphology. 70, 357-371.

Assine, M.L., 2015. Brazilian Pantanal: a large pristine tropical wetland. In: Vieira, B.C., Salgado, A.A.R., Santos, L.J.C. (Eds.), Landscapes and landforms of Brazil. Springer, pp. 135-146.

Assine, M.L., Corradini, F.A., Pupim, F.N., McGlue, M.M., 2014. Channel arrangements and depositional styles in the São Lourenço fluvial megafan, Brazilian Pantanal wetland. Sedimentary Geology. 301, 172-184.

Barbiero, L., Furian, S., Queiroz Neto, J.P., Ciornei, G., Sakamoto, A.Y., Capellari, B., Fernandes, E., Valles, V., 2002. Geochemistry of water and ground water in the Nhecolândia, Pantanal of Mato Grosso, Brazil: variability and associated processes. Wetlands. 22, 528-540.

Beirigo, R.M., Vidal-Torrado, P., Stape, J.L., Andrade, G.R.P., 2010. Solos da Reserva Particular do Patrimônio Natural SESC Pantanal. Conhecendo o Pantanal 7. Serviço Social do Comércio. 76 p.

Berendsen, H.J.A., Stouthamer, E., 2000. Late Weichselian and Holocene palaeogeography of the Rhine-Meuse delta. The Netherlands. Palaeogeography, Palaeoclimatology, Palaeoecology. 161, 311-335.

Bertaux, J., Sondag, F., Santos, R., Soubiès, F., Causse, C., Plagnes, V., Le Cornec, F., Seidel, A., 2002. Paleoclimatic record of speleothems in a tropical region: study of laminated sequences from a Holocene stalagmite in Central-West Brazil. Quat. Int. 89, 3-16.

Bohn, H.L., McNeal, B.L., O'Connor, G.A., 2001. Soil Chemistry. 3rd edition. JohnWiley and Sons, New York. 322 p.

Bond, W.J., 1986. Illuvial band formation in a laboratory column of sand. Soil Sci. Soc. Am. J. 50, 265-267.

Bruinsma, J., 2003. World agriculture: towards 2015/2013. An FAO perspective. Earthscan Publication Ltd, London.

Bryant, M., Falk, P., Paola, C., 1995. Experimental study of avulsion frequency and rate of deposition. Geology. 23, 365-368.

Bullock P, Federoff N, Jongerius A, Stoops G, Tursina T., 1985. Handbook for Soil Thin Section Description. Waine Research Publications, London.

Cazanacli, D.; Smith, N., 1998. A study of morphology and texture of natural levees - Cumberland Marshes, Saskatchewan, Canada. Geomorphology. 25, 43-55.

Chernousenko, G.I., Kalinina, N.V., Khitrov, N.B., Pankova, E.I., Rukhovich, D.I., Yamnova, I.A., Novikova, A.F., 2011. Quantification of the areas of saline and solonetzic soils in the Ural Federal region of the Russian Federation. Eurasian Soil Science. 44, 67-379.

Couto, E. G., Oliveira, V.A., Beirigo, R.M., Oliveira Junior, J.C., Nascimento, A.F., Vidal-Torrado, P., 2017. Solos do Pantanal Matogrossense. In N. Curi, J.C. Ker, R.F. Novais, P. Vidal-Torrado, C.E.G.R. Schaefer (Eds) Pedologia. Solos dos Biomas Brasileiros. Sociedade Brasileira de Ciência do Solo, Viçosa. pp. 303-352. 
Del'Arco, J.O., Silva, R.H., Tarapanoff, I., Freire, F.A., Pereira, L.G.M., Souza, S.L., Luz, D.S., Palmeira, R.C.B., Tassinari, C.C.G.,1982. Geologia da Folha SE.21 Corumbá e Parte da Folha SE.20. RADAMBRASIL-Levantamento dos Recursos Naturais. Rio de Janeiro, pp. 25-160.

Droubi, A. Al, Fritz, B., Gac, J. Y., Tardy, Y., 1980. Generalized residual alkalinity concept: Application to prediction of the chemical evolution of natural waters by evaporation, Amer. J. Sci. 280, 560-572.

Empresa Brasileira De Pesquisa Agropecuária - EMBRAPA, 1997. Manual de métodos de análise de solo. 2.ed. Rio de Janeiro.

Fanning, D.S., Fanning, M.C.B.,1989. Soil, Morphology, Genesis, and Classification. John Wiley \& Sons, New York.

FAO, 2006. Guidelines for Soil Description, 4th ed. FAO, Rome.

Fehrenbacher, J.B., Wilding, L.P., Odell, R.T., Melsted, S.W., 1963. Characteristics of solonetzic soils in Illinois. Soil Science Society Proceedings. 27, 421-431.

Fitzpatrick, R.W., Boucher, S.C., Naidu, R., Fritsch, E., 1994. Environmental consequences of soil sodicity. Australian Journal of Soil Research. 32, 1069-1093.

Furquim, S.A.C, Santos, M.A.S., Vidoca, T.T., Balbino, M.A., Cardoso, E.L., 2017. Salt-affected soils evolution and fluvial dynamics in the Pantanal wetland, Brazil. Geoderma. 286, 139-152.

Furquim, S.A.C., Graham, R., Barbiero, L., Queiroz Neto, J.P., Vallès, V., 2008. Mineralogy and genesis of smectites in an alkaline-saline environment of Pantanal wetland, Brazil. Clay Clay Miner. $56,580-596$.

Furquim, S.A.C., Graham, R.C., Barbiero, L., Queiroz Neto, J.P., Vidal-Torrado, P., 2010. Soil mineral genesis and distribution in a saline lake landscape of the Pantanal Wetland, Brazil. Geoderma. $154,518-528$.

Garcia, E.A.C., 1991. Zoneamento agroecológico e socioeconômico da bacia hidrográfica brasileira do rio Paraguai: uma abordagem numérica preliminar. Embrapa Pantanal.

Gedroiz, K.K., 1925. Soil absorbing complex and the absorbed soil cations as a basis of genetic soil classification. Nosovka Agricultural Experimental Station. 38 (Translation into English: S.A. Waksman).

Godoi Filho, J.D., 1986. Aspectos Geológicos do PantanalMato-Grossense e de sua Área de Influência. In: Anais do 1o Simpósio sobre Recursos Naturais e Sócio-Econômicos do Pantanal, 27 de novembro a 4 de dezembro de 1984, Corumbá (MS), pp. 63-76.

Heck, R.J., Mermut, A.R., 1992. Genesis of Natriborolls (Solonetzic) in a close lake basin in Saskatchewan, Canada. Soil Sci. Soc. Am. J. 56, 842-848.

Indorante, S., 2006. Sodium-affected soils in humid areas. In R. Lal (Ed.) Encyclopedia of Soil Science, $2^{\text {nd }}$ edition, 1606-1609.

IUSS Working Group WRB. World Reference Base for Soil Resources, 2014 (update 2015). International soil classification system for naming soils and creating legends for soil maps. World Soil Resources Reports No. 106. FAO, Rome. 2015. (Available in http://www.fao.org/3/ai3794e.pdf)

Köppen, W., 1936. Das geographische system der klimate. In: Köppen, W., Geiger, R. (Eds.), Handbuch der Klimatologie 1, Part C. Gebruder Borntraeger, Berlin, 46 pp. 
MacKay, A.W.; Davidson, T.; Wolski, P.; Mazebedi R.; Masamba, W.R.L.; Hunts-Mapila, P; Todd, M., 2011. Spatial and Seasonal variability in surface water chemistry in the Okavango Delta, Botswana: a multivariate approach. Wetlands. 31, 815-829.

Makaske, B.; Maathuis, B.H.; Padovani, C.R.; Stolker, C.; Mosselman, E.; Jongman, R.H.G., 2012. Upstream and downstream controls of recent avulsions on the Taquari megafan, Pantanal, southwestern Brazil. Earth Surface Processes and Landforms. 37, 1313-1326.

Martinez-Beltran J, Manzur CL., 2005. Overview of salinity problems in the world and FAO strategies to address the problem. Proceedings of the international salinity forum, Riverside, California, pp. 311-313.

Massoud, F.I., 1977. Basic principles for prognosis and monitoring of salinity and sodicity. Proceedings of the international conference on management of saline water for irrigation, Lubbock, Texas, pp.432-454.

McBride, M.B., 1994. Environmental chemistry of soils. Cap.8, Salt-affected and Swelling Soils. Oxford University Press (18 p.).

McCarthy, T.S.; Ellery, W.N.; Stanistreet, I.G., 1992. Avulsion mechanisms on the Okavango fan, Botsuana: the control of a fluvial system by vegetation. Sedimentology. 39, 779-795.

McGlue, M.M., Silva, A., Zani, H., Corradini, F.A., Parolin, M., Abel, E.J., Cohen, A.S., Assine, M.L., Trees, M.A., Kuerten, S., dos Santos Gradella, F., Rasbold, G.G., 2012. Lacustrine records of Holocene flood pulse dynamics in the Upper Paraguay River watershed (Pantanal wetlands, Brazil). Quat. Res. 78, 285-294.

Meier, S.D.; Atekwana, E.A; Molwalefhe, L.; Atekwana, E.A., 2015. Processes that control water chemistry and stable isotopic composition during the refilling of lake Ngami in semiarid northwest Botswana. Journal of Hydrology527, 420-432.

Monteiro, F.M., Fonseca, M.M., Madeira, M.A., Herbillon, A.J., 2012. Driving factors determining the occurrence of Sodic soils in dry subhumid Mediterranean areas. Journal of Plan Nutrition and Soil Science. $175,94-100$.

Morosova, G.S.; Smith, N.D., 1999. Holocene avulsion history of the lower Saskatchewan fluvial system, Cumberland Marches, Saskatchewan-Manitoba, Canada. Spec. Publs Int. Ass. Sediment. 28, 231-249.

Munn, L.C., Boehm, M.M., 1983. Soil genesis in a Natrargid-Haplargid complex in northern Montana. Soil Sci. Soc. Am. J. 47, 1186-1192.

Nascimento, A.F, Furquim, S.A.C., Couto, E.G., Beirigo, R.M., Oliveira Junior, J.C., Camargo, P.B., Vidal-Torrado, P., 2013. Genesis of textural contrasts in subsurface soil horizons in the Northern Pantanal-Brazil. Revista Brasileira de Ciência do Solo. 37, 1113-1127.

Nascimento, A.F., 2012. Relações pedologia-geomorfologia-sedimentologia no Pantanal Norte. Tese de Doutorado. Departamento de Solos. Escola Superior de Agricultura Luiz de Queiroz ESALQ/USP. doi:10.11606/T.11.2012.tde-06072012-103745.

Nascimento, A.F., Furquim, S.A.C., Graham, R.C., Beirigo, R.M., Oliveira Junior, J.C., Couto, E.G., Vidal-Torrado, P., 2015. Pedogenesis in a Pleistocene fluvial system of the Northern Pantanal Brazil. Geoderma. 255-256, 58-72. doi:10.1016/j.geoderma.2015.04.025

Nichols, G., 2009. Sedimentology and Stratigraphy. $2^{\text {nd }}$ edition. United Kingdom. Wiley-Blackwell, $419 \mathrm{p}$.

Oliveira Junior, J.C., Beirigo, R.M., Chiapini, M., do Nascimento, A.F., Couto, E.G., Vidal-Torrado, P., 2017a. Origin of mounds in the Pantanal wetlands: An integrated approach between 
geomorphology, pedogenesis, ecology and soil micromorphology. PLoS One. 12, e0179197. doi:10.1371/journal.pone.0179197

Oliveira Junior, J.C., Chiapini, M., Nascimento, A.F., Couto, E.G., Beirigo, R.M., Vidal-Torrado, P., 2017b. Genesis and Classification of Sodic Soils in the Northern Pantanal. Rev. Bras. Cienc. do Solo. 41, e0170015. doi: 10.1590/18069657rbcs20170015.

Oliveira, H., Carvalho Filho, A., Schaefer, C.E.R.G., Cardoso, E.L., 2006. Soils of the Pantanal. In: Chesworth, W. Encyclopedia of Soil Science, Dordrecht: Taylor \& Francis. p. 1658-1663.

Padovani, C.R., 2010. Dinâmica espaço-temporal das inundações no Pantanal. Escola Superior de Agricultura Luiz de Queiroz (Esalq), Universidade de São Paulo, Tese de Doutorado.

Pansu, M., Gautheyrou, J, 2006. Handbook of soil analysis: mineralogical, organic and inorganic methods. Berlin: Springer. 993 p.

PiPujol, M.D., Buurman, P., 1994. The distinction between ground-water gley and surface-water gley phenomena in Tertiary paleosols of the Ebro basin, NE Spain. Palaeogeography, Palaeoclimatology, Palaeoecology. 110, 103-113

Por, F.D., 1995. The Pantanal of Mato Grosso (Brazil) — World's Largest Wetlands. Klumer Ac. Publ. (122 p.).

Pupim, F.N.; Assine, M.L.; Sawakuchi, A.O., 2017. Late Quaternary Cuiabá megafan, Brazilian Pantanal: channels patterns and paleoenvironmental changes. Quaternary International. 438, 108-125.

Rengasamy, P., 2006. World salinization with emphasis on Australia. Journal of Experimental Botany. 57, 1017-1023.

Rengasamy, P., Sumner, M.E., 1998. Processes involved in sodic behavior. In M.E. Sumner and R. Naidu (Eds.) Sodic Soils: distribution, properties, management and environmental consequences. Oxford University Press, New York, p. 35-50.

Rezende Filho, A.T., Furian, S., Victoria, R.L., Mascré, C., Valles, V., Barbiero, L., 2012. Hydrochemical variability at the Upper Paraguay Basin and Pantanal wetland. Hydrology and Earth System Sciences. 16, 2723-2737.

Sandoval, F.M., Reichman, G.A., 1971. Some properties of Solonetzic (Sodic) soils in western North Dakota. Can. J. Soil Sci. 51, 143-155.

Sandoval, F.M., Shoesmith, L., 1961. Genetic soil relationship in a saline glacio-lacustrine area. Soil Science Society Proceedings. 25, 316-320.

Sawula, G., Martins, E., 1991. Major ion chemistry of the lower Boro River, Okavango Delta, Botswana. Freshwater Biology. 26, 481-493.

Schaetzl, R.J., Anderson, S., 2005. Soils, Genesis and Geomorphology. Cambridge University Press, Cambridge. 817 pp.

Schumm, S.A., 1977. The Fluvial System. Wiley. 338 p.

Silva, J.S.V., Abdon, M.M., 1998. Delimitação do Pantanal brasileiro e suas sub-regiões. Pesquisa Agropecuária Brasileira. 33, 1703-1711.

Silva, T.C., 1986. Contribuição da Geomorfologia para o Conhecimento e Valorização do Pantanal. In: Anais do $1^{\circ}$ Simpósio sobre Recursos Naturais e Sócio-Econômicos do Pantanal, Corumbá. pp. 77-90.

Singh, N., Kar, A., 2001. Characteristics of major soils of Banni mudflat in arid western India and their relationship with topography. Journal of Arid Environment. 48, 509-520. 
Sinha, R.; Friend, P., 1994. River systems and their sediment flux, Indo-Gangetic plains, Northern Bihar, India. Sedimentology. 41, 825-845.

Soil Survey Staff. Keys to Soil Taxonomy, 2014. 12th ed. Washington: USDA-Natural Resources Conservation Service.

Stoops, G., 2003. Guidelines for Analysis and Description of Soil and Regolith Thin Sections. Soil Science Society of America, Madison, Wisconsin.

Stouthamer, E., 2001. Sedimentary products of avulsions in the Holocene Rhine-Meuse Delta, The Netherlands. Sedimentary Geology. 145, 73-92.

Stouthamer, E., Berendsen, H.J.A., 2007. Avulsion: the relative roles of autogenic and allogenic processes. Sedimentary Geology. 198, 309-325.

Szabolcs, I., 1974. Salt affected soils in Europe. Martinus Nijhoff, The Hague. 63 p.

Szabolcs, I., 1979. Review of research on salt affected soils. Natural Resources Research XV, Unesco, Paris.

Tarifa, J.R., 1986. O Sistema Climático do Pantanal: da compreensão do sistema à definição de prioridades de pesquisa climatológica. In: Anais do $1^{\circ}$ Simpósio sobre Recursos Naturais e SócioEconômicos do Pantanal, Corumbá. pp. 9-27.

Thomas, M., Fitzpatrick, R.W., Heinson, G.S., 2011. Spatial and temporal trends in soil salinity for identifying perched and deep groundwater systems. Soil Use and Management. 27, 264-279.

Tornqvist, T., 1994. Middle and late Holocene avulsion history of the River Rhine (Rhine-Meuse delta, Netherlands). Geology. 22, 711-714.

United States Department of Agriculture - USDA, 1996. Soil Survey Laboratory Methods Manual. Soil Survey Investigations Report.

USSL Staff, 1954. Diagnosis and Improvement of Saline and Alkali Soils. U. S. Department of Agriculture, United States Salinity Laboratory (USSL), Washington Handbook, n. 60, 160 p.

Wallinga, J., Murray, A., Wintle A., 2000. The single-aliquot regenerative-dose (SAR) protocol applied to coarse-grain feldspar. Radiation Measurements. 32, 529-533.

Westin, F.C., 1953. Solonetz soils on eastern South Dakota: their properties end genesis. Soil Sci. Soc. Am. Proc. 17, 287-293.

Whitney, B.S., Mayle, F.E., Surangi,W.P., Fitzpatrick, K.A., Burn, M.J., Guillen, R., Chavez, E., Mann, D., Pennington, R.T., Metcalfe, S.E., 2011. A $45 \mathrm{kyr}$ palaeoclimate record from the lowland interior of tropical South America. Palaeogeogr. Palaeoclimatol. Palaeoecol. 307, 177-192.

Whittig, L.D., 1959. Characteristics and genesis of a Solodized Solonetz of California. Soil Sci. Soc. Am. Proc. 23, 469-473.

Yang, F., Zhang, G., Yin, X., Liu, Z., 2011. Field-scale spatial variation of saline-sodic and its relation with environmental factors in western Songnen plain of China. Int. J. Environ. Res. Public Health. 8, 374-387.

Zani, H., Assine, M.L., Silva, A., Corradini, F.A., 2009. Redes de drenagem distributária e formas posicionais no megaleque do Taquari, Pantanal: uma análise baseada no MDE-SRTM. Revista Brasileira de Geomorfologia. 10, 21-28. 